\title{
Metal Ion Activation of Clostridium sordellii Lethal Toxin and Clostridium difficile Toxin B
}

\author{
Harald Genth *, Ilona Schelle and Ingo Just \\ Institute for Toxicology, Hannover Medical School, Carl-Neuberg-Str. 1, D-30625 Hannover, Germany; \\ Ilona.Schelle@t-online.de (I.S.); just.ingo@mh-hannover.de (I.J.) \\ * Correspondence: genth.harald@mh-hannover.de; Tel.: +49-511-532-9168 \\ Academic Editor: Holger Barth \\ Received: 21 March 2016; Accepted: 5 April 2016; Published: 13 April 2016
}

\begin{abstract}
Lethal Toxin from Clostridium sordellii (TcsL) and Toxin B from Clostridium difficile (TcdB) belong to the family of the "Large clostridial glycosylating toxins." These toxins mono-O-glucosylate low molecular weight GTPases of the Rho and Ras families by exploiting UDP-glucose as a hexose donor. TcsL is casually involved in the toxic shock syndrome and the gas gangrene. TcdB-together with Toxin A (TcdA) - is causative for the pseudomembranous colitis (PMC). Here, we present evidence for the in vitro metal ion activation of the glucosyltransferase and the UDP-glucose hydrolysis activity of TcsL and TcdB. The following rating is found for activation by divalent metal ions: $\mathrm{Mn}^{2+}>\mathrm{Co}^{2+}>\mathrm{Mg}^{2+}>>\mathrm{Ca}^{2+}, \mathrm{Cu}^{2+}, \mathrm{Zn}^{2+}$. TcsL and $\mathrm{TcdB}$ thus require divalent metal ions providing an octahedral coordination sphere. The $\mathrm{EC}_{50}$ values for TcsL were estimated at about $28 \mu \mathrm{M}$ for $\mathrm{Mn}^{2+}$ and $180 \mu \mathrm{M}$ for $\mathrm{Mg}^{2+}$. TcsL and TcdB further require co-stimulation by monovalent $\mathrm{K}^{+}$(not by $\mathrm{Na}^{+}$). Finally, prebound divalent metal ions were dispensible for the cytopathic effects of TcsL and $\mathrm{TcdB}$, leading to the conclusion that TcsL and TcdB recruit intracellular metal ions for activation of the glucosyltransferase activity. With regard to the intracellular metal ion concentrations, TcsL and $\mathrm{TcdB}$ are most likely activated by $\mathrm{K}^{+}$and $\mathrm{Mg}^{2+}$ (rather than $\mathrm{Mn}^{2+}$ ) in mammalian target cells.
\end{abstract}

Keywords: glycosyltransferase; UDP-glucose hydrolysis; cytopathic effect; Rho; Ras; manganese; transepithelial resistance; small GTPases; Madin-Darby canine kidney (MDCK-C7) cells

\section{Introduction}

Lethal Toxin (TcsL) from Clostridium sordellii and Toxin B from Clostridium difficile (TcdB) belong to the family of the "Large clostridial glycosylating toxins" (LCGTs). The LCGTs further encompass the hemorrhagic toxin (TcsH) from C. sordellii, toxin A (TcdA) from C. difficile, alpha-toxin (Tcn $\alpha)$ from Clostridium novyi, and the glycosylating toxin (TcpE) from Clostridium perfringens type E strains [1,2]. The LCGTs exhibit a multidomain structure harboring domains required for self-mediated cell entry. Thereby, the N-terminally located glycosyltransferase domain enters the target cell cytosol by receptor-mediated endocytosis (short trip uptake). The glycosyltransferase domain catalyzes the transfer of a glucose moiety or-in the cases of Tcn $\alpha$ and TcpE-of a N-acetylglucosamine moiety to small GTPases of the Rho and Ras subfamilies. In particular, TcsL glucosylates the Ras family GTPases (H/K/N/R) Ras, Rap1/2, and Ral, as well as the Rho family GTPases Rac and Cdc42, while TcdB specifically glucosylates Rho, Rac, and Cdc42 subfamily GTPases [3-5]. Mono-glucosylation at Thr-35/-37, a pivotal residue within the effector loop of Rho-/Ras-GTPases, prevents GTP-driven activation of Ras/Rho proteins, resulting in functional inactivation of the GTPases [6,7]. In cultured cells, substrate GTPase glucosylation by TcsL and TcdB results in a loss of cell-cell- and cell-matrix-interaction [8-10] and in cell death including upregulation and activation of the cell death-regulating GTPase RhoB [11-14]. TcsL-induced loss of cell-matrix adhesion, a hallmark 
of TcsL cytopathic activity, depends on disassembly of focal adhesion complexes rather than of actin depolymerization $[9,15]$.

The 3D structures of $\mathrm{TcdB}$ and TcsL have led to their classification as type A glycosyltransferases [16,17]. The enzymatic activity of type A glycosyltransferases employing nucleotide hexoses depends on divalent metal ions. In the absence of their substrate GTPase, the LCGTs exhibit UDP-hexose hydrolysis activity. While the metal ion dependencies of UDP-glucose hydrolysis activity of TcdB and TcdA have been evaluated in some detail [18,19], data on the metal ion dependency of the glucosyltransferase activity of the LCGTs and of TcsL in particular are not available. We here show that the glucosyltransferase and the UDP-glucose hydrolysis activities of recombinant glucosyltransferase domains of TcsL $(\mathrm{rN}-\mathrm{TcsL})$ and of TcdB $(\mathrm{rN}-\mathrm{TcdB})$ are strongly stimulated by monovalent and divalent metal ions in cell-free systems.

\section{Results and Discussion}

\subsection{Divalent Metal Ion Dependency of TcsL}

The divalent metal ion requirement of the glucosyltransferase activity of TcsL was evaluated in a cell-free system using the recombinantly prepared the N-terminally located domain of TcsL (rN-TcsL) and Rac1 as substrate GTPase in the presence of UDP- $\left[{ }^{14} \mathrm{C}\right]$ glucose. $\mathrm{Mn}^{2+}$ turned out to be the most efficacious activator of rN-TcsL glucosyltransferase activity, whereas $\mathrm{Co}^{2+}$ and $\mathrm{Mg}^{2+}$ were partial activators (Figure 1). $\mathrm{Zn}^{2+}$ also stimulated rN-TcsL activity to some extent, whereas $\mathrm{Ca}^{2+}$ and $\mathrm{Cu}^{2+}$ did not. Remarkable transferase activity was observed in the absence of added divalent metal ions (none) due to the presence of $\mathrm{Mg}^{2+}$ required for the stability of the substrate GTPase. The analysis of divalent metal ion requirement of $\mathrm{rN}-\mathrm{TcsL}$ was thus biased by the $\mathrm{Mg}^{2+}$ requirement of the substrate GTPase (Figure 1).

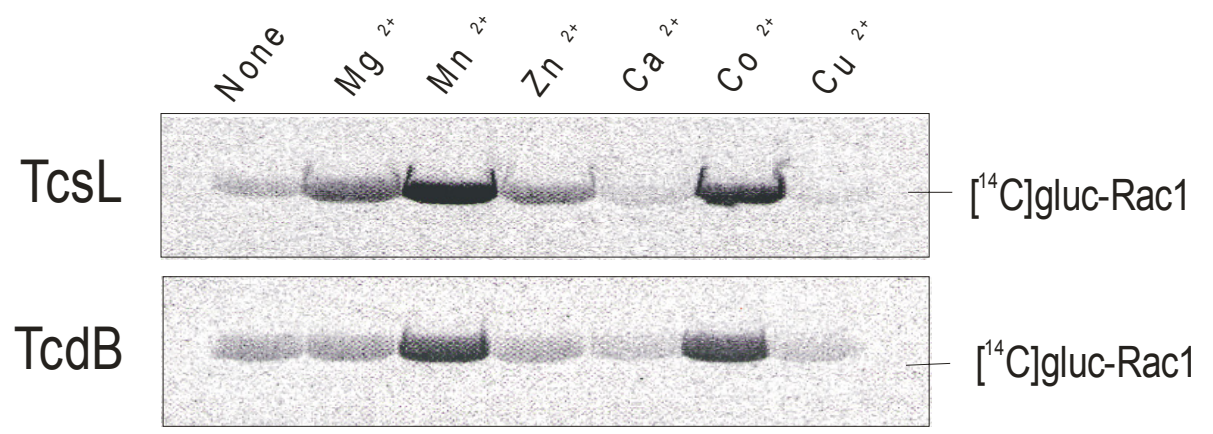

Figure 1. Divalent metal ion-activated glycosyltransferase activity of $C$. sordellii lethal toxin (TcsL). Rac1 $(50 \mu \mathrm{g} / \mathrm{mL})$ and $\mathrm{rN}-\mathrm{TcsL}(0.3 \mathrm{nM})$ or $\mathrm{rN}-\mathrm{TcdB}(0.3 \mathrm{nM})$ as indicated were incubated in the presence of the indicated divalent metal ions $(1 \mathrm{mM})$ at $37^{\circ} \mathrm{C}$ for $10 \mathrm{~min}$. $\left[{ }^{14} \mathrm{C}\right]$ glucosylated Rac1 was separated by SDS-page and visualized by autoradiography.

In the absence of substrate GTPases, rN-TcsL catalyzes hydrolytic cleavage of UDP-glucose into UDP and glucose (UDP-glucose hydrolysis activity), which is exploited as a surrogate for the physiologically relevant glucosyltransferase activity [18-20]. In the absence of rN-TcsL, spontaneous hydrolysis in the presence of $\mathrm{Mn}^{2+}$ was barely detected at neutral $\mathrm{pH}$, as analyzed upon thin layer chromatography (PEI-cellulose as matrix) for the separation of UDP- $\left[{ }^{14} \mathrm{C}\right]$ glucose (educt) and $\left[{ }^{14} \mathrm{C}\right]$ glucose (product) (Figure 2A). Proton-catalyzed hydrolysis of UDP-glucose into UDP and $\left[{ }^{14} \mathrm{C}\right]$ glucose was applied as control to prove that the spot assigned to glucose was in fact $\left[{ }^{14} \mathrm{C}\right]$ glucose (Figure 2A). Freshly prepared rN-TcsL exhibited only (if any) poor UDP-glucose hydrolysis activity in the presence of monovalent $\mathrm{K}^{+}$(Figure 2A). This activity was strongly stimulated in the presence of several divalent metal ions $(1 \mathrm{mM}$ each), and the following rating was found (Figure 2B): $\mathrm{Mn}^{2+}>\mathrm{Co}^{2+}>\mathrm{Mg}^{2+}>\mathrm{Zn}^{2+}, \mathrm{Ca}^{2+}, \mathrm{Cu}^{2+}$. Thus, divalent metal ion requirement of 
glucosyltransferase (Figure 1) and UDP-glucose hydrolysis activity (Figure 2B) were almost comparable. In the presence of the chelator EDTA $(1 \mathrm{mM})$, rN-TcsL-catalyzed UDP-glucose hydrolysis activity was almost completely suppressed, supporting the essential role of divalent metal ions in enzyme activity (Figure 2B). The finding that $\mathrm{Ca}^{2+}$ failed to activate both glucosyltransferase activity (Figure 1) and UDP-glucose hydrolysis activity (Figure 2B) is consistent with structural data showing that the active center of rN-TcsL is disassembled in the presence of $\mathrm{Ca}^{2+}$ (albeit $\mathrm{Ca}^{2+}$ being capable of mediating UDP-glucose binding to rN-TcsL) [16]. rN-TcsL glucosyltransferase activity and UDP-glucose hydrolysis activity thus seems to depend on divalent metal ions providing a strictly octahedral coordination sphere including $\mathrm{Mn}^{2+}, \mathrm{Co}^{2+}$, or $\mathrm{Mg}^{2+}$ (Figure 2B).
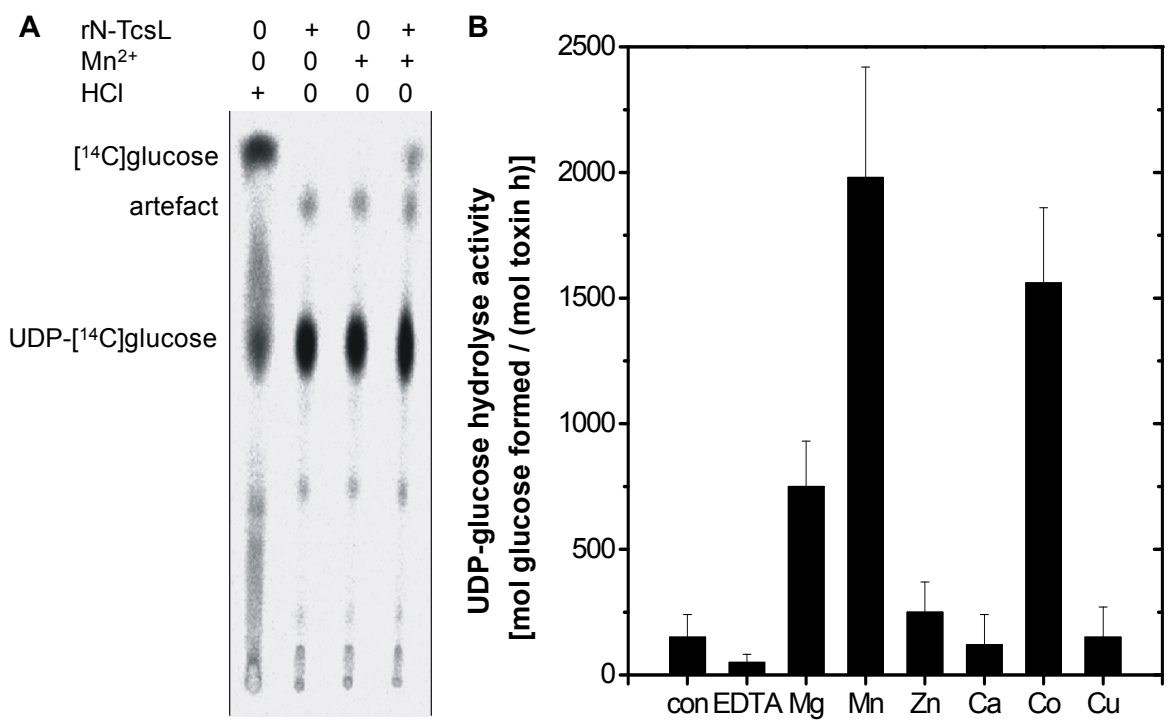

Figure 2. Divalent metal ion-activated UDP-glucose hydrolysis activity of $C$. sordellii lethal toxin (TcsL). (A) UDP-[ $\left[{ }^{14} \mathrm{C}\right]$ glucose $(100 \mu \mathrm{M})$ was incubated in the presence of $0.1 \mathrm{M} \cdot \mathrm{HCl}$ with $\mathrm{Mn}^{2+}$ $(1 \mathrm{mM})$ and $\mathrm{rN}-\mathrm{TcsL}(100 \mathrm{nM})$ as indicated at $37{ }^{\circ} \mathrm{C}$ for $30 \mathrm{~min}$. UDP- $\left[{ }^{14} \mathrm{C}\right] \mathrm{glucose}$ and $\left[{ }^{14} \mathrm{C}\right] \mathrm{glucose}$ were separated by thin layer chromatography on PEI cellulose and visualized by autoradiography. (B) UDP- $\left[{ }^{14} \mathrm{C}\right]$ glucose $(100 \mu \mathrm{M})$ was incubated in the presence of $\mathrm{rN}-\mathrm{TcsL}(100 \mathrm{nM})$ with the indicated divalent metal ions $(1 \mathrm{mM})$ at $37^{\circ} \mathrm{C}$ for $30 \mathrm{~min}$. Signal intensities of formed $\left[{ }^{14} \mathrm{C}\right]$ glucose were quantified and are given as means $\pm \operatorname{SD}(n=3)$.

UDP-glucose hydrolysis activity of rN-TcsL was next analyzed in the presence of increasing concentrations of the most efficacious divalent metal activator $\mathrm{Mn}^{2+}$ and the partial divant metal activator $\mathrm{Mg}^{2+}$. The UDP-glucose hydrolysis activity versus divalent metal concentration curve exhibited a sigmoid shape (Figure $3 \mathrm{~A}$ ). The $\mathrm{EC}_{50}$ values were estimated to about $28 \mu \mathrm{M}$ for $\mathrm{Mn}^{2+}$ and $180 \mu \mathrm{M}$ for $\mathrm{Mg}^{2+}$ using the sigmoid $\mathrm{E}_{\max }$ model. $\mathrm{Mn}^{2+}$ thus turned out to be the most efficacious divalent metal ion activator in vitro. Albeit being the most efficacious divalent metal ion activator in vitro, $\mathrm{Mn}^{2+}$ (as well as $\mathrm{Co}^{2+}$ ) may be excluded as intracellular activators of TcsL due to their low free intracellular concentrations of maximal $1 \mu \mathrm{M}$. rN-TcsL more likely meets activating levels of $\mathrm{Mg}^{2+}$, which free intracellular concentration is in the millimolar range [21]. 

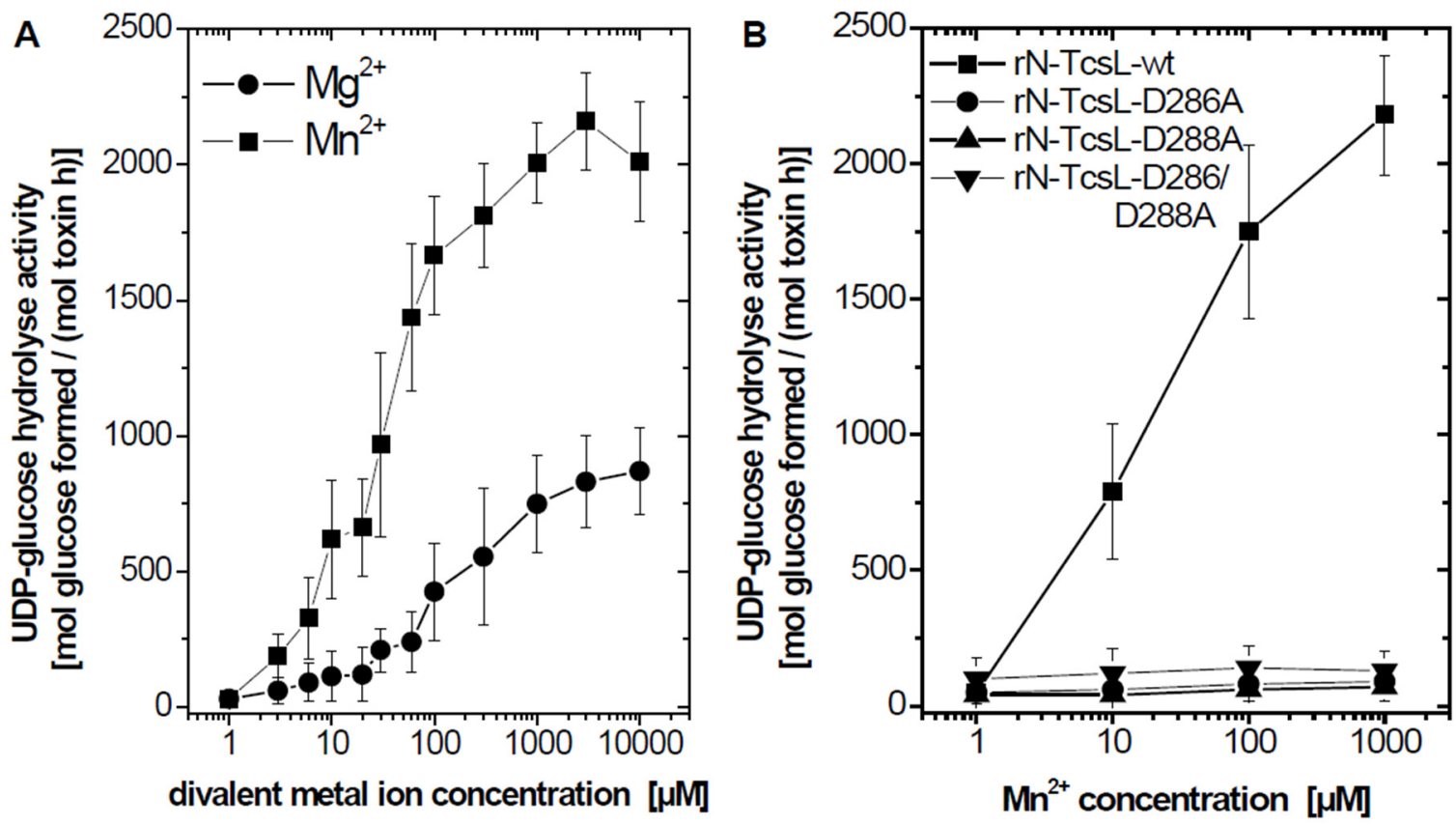

Figure 3. Divalent metal ion activation of $\mathrm{rN}-\mathrm{TcsL}$. A. UDP- $\left[{ }^{14} \mathrm{C}\right]$ glucose $(100 \mu \mathrm{M})$ was incubated in the presence of $\mathrm{rN}-\mathrm{TcsL}(100 \mathrm{nM})$ with the indicated concentrations of $\mathrm{Mn}^{2+}$ or $\mathrm{Mg}^{2+}$ at $37{ }^{\circ} \mathrm{C}$ for $30 \mathrm{~min}$. B. UDP-[ $\left.{ }^{14} \mathrm{C}\right]$ glucose $(100 \mu \mathrm{M})$ was incubated in the presence of $\mathrm{rN}-\mathrm{TcsL}(100 \mathrm{nM})$ and the indicated rN-TcsL mutants $(1 \mu \mathrm{M})$ with the indicated concentrations of $\mathrm{Mn}^{2+}$ at $37{ }^{\circ} \mathrm{C}$ for $30 \mathrm{~min}$. UDP- $\left[{ }^{14} \mathrm{C}\right]$ glucose and $\left[{ }^{14} \mathrm{C}\right]$ glucose were separated by thin layer chromatography on PEI cellulose and visualized by autoradiography. Signal intensities of formed $\left[{ }^{14} \mathrm{C}\right]$ glucose are quantified and given as mean $\pm \mathrm{SD}(n=3)$.

\subsection{Essential Role of the DxD Motif for $\mathrm{Mn}^{2+}$-Activated UDP-Glucose Hydrolysis Activity}

The divalent metal-dependent coordination of UDP-hexoses within the catalytic cleft of all members of the LCGT family requires the Asp-any amino acid-Asp (DxD) motif [22]. From the 3D-structure of rN-TcsL, it can be deduced that Asp-288 directly binds to $\mathrm{Mn}^{2+}$, whereas Asp-286 binds the ribosyl and glucosyl moieties of UDP-glucose [16]. To further provide evidence on essential role of the DxD in $\mathrm{Mn}^{2+}$-activated UDP-glucose hydrolysis activity, the glycohydrolase activity was analyzed using several rN-TcsL versions with mutant DxD motif including rN-TcsL-D286A, rN-TcsL-D288A, as well as the double mutant rN-TcsL-D286A-D288A [20]. Exchange of either aspartate residue was sufficient to completely block $\mathrm{Mn}^{2+}$-activated UDP-glucose hydrolysis activity (Figure 3B). The DxD motif is thus essential for $\mathrm{Mn}^{2+}$-dependent UDP-glucose hydrolysis activity of TcsL. These observations are consistent with former data showing that either exchange of either Asp abolishes the rN-TcsL glucosyltransferase activity [20]. Divalent metal ion activation of rN-TcsL depends on the DxD motif.

\subsection{Monovalent Metal Ion Dependency of rN-TcsL UDP-Glucose Hydrolysis Activity}

Besides activation by divalent metal ions, several enzymes from eukaryotic and prokaryotic organisms require monovalent metal ions. Monovalent metal ions thereby contribute to anchoring the substrate to the catalytic cleft of the enzyme [23]. To check if rN-TcsL activity depends on monovalent metal ions, UDP-glucose hydrolysis activity was determined in the presence of $1 \mathrm{mM}$ of $\mathrm{Mn}^{2+}$ and either $\mathrm{KCl}$ or $\mathrm{NaCl}$ (Figure 4A). UDP-glucose hydrolysis of $\mathrm{rN}$-TcsL activity was selectively stimulated by increasing concentrations of $\mathrm{KCl}$ (not of $\mathrm{NaCl}$ ) (Figure 4A). Thus, besides activation by divalent metal ions, monovalent $\mathrm{K}^{+}$is an essential co-activator of the rN-TcsL UDP-glucose hydrolysis activity. The requirement for co-activation by $\mathrm{K}^{+}$has also been reported for TcdB and TcdA $[18,19]$. The intracellular concentrations of $\mathrm{K}^{+}$and $\mathrm{Na}^{+}$range from 100 to $155 \mathrm{mM}$ and from 8 to $30 \mathrm{mM}$, respectively. LCGTs thus 
seem to be optimally adapted to the monovalent metal ion conditions in the cytosol of its mammalian target cells. As neither $\mathrm{K}^{+}$or $\mathrm{Mg}^{2+}$ alone turn out to be sufficient for $\mathrm{rN}$-TcsL activation, $\mathrm{K}^{+} \mathrm{and} \mathrm{Mg}^{2+}$ may act in tandem to provide optimal docking for the pyrophosphate of the UDP-glucose into the catalytic cleft of the LCGTs, as suggested for several other $\mathrm{K}^{+}$-activated enzymes [23].
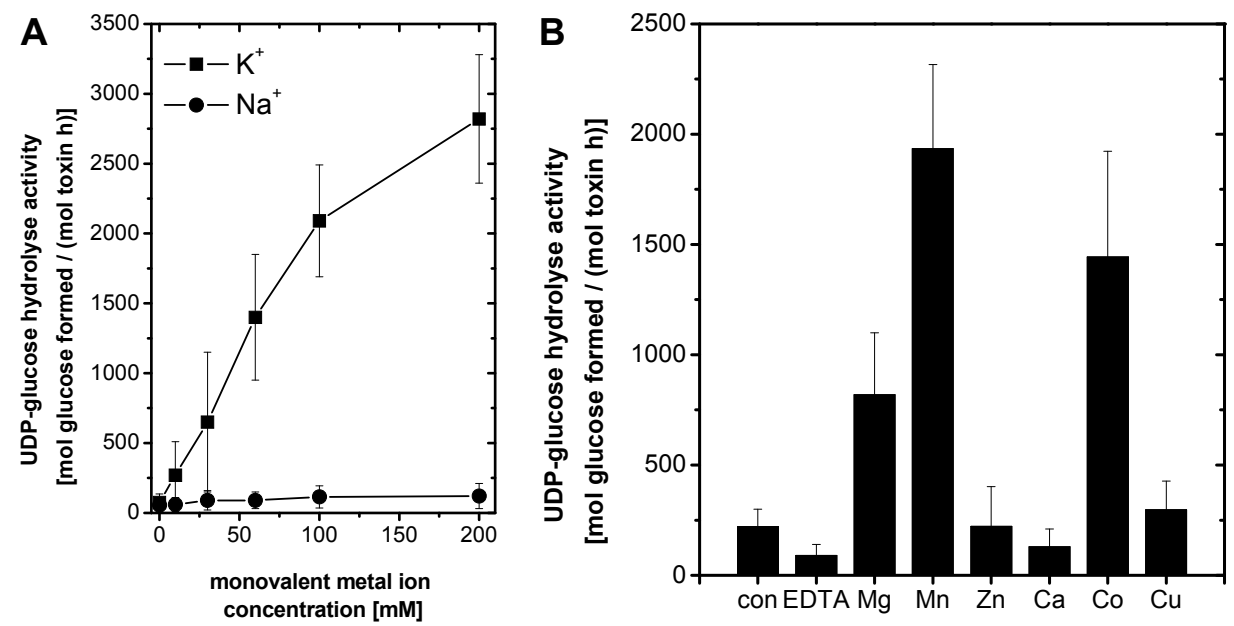

Figure 4. (A) $\mathrm{K}^{+}$is an essential co-activator of rN-TcsL. rN-TcsL $(100 \mathrm{nM})$ was incubated with $100 \mu \mathrm{M} \cdot \mathrm{UDP}-\left[{ }^{14} \mathrm{C}\right]$ glucose in the presence of $1 \mathrm{mM} \cdot \mathrm{Mn}^{2+}$ and increasing concentrations of $\mathrm{K}^{+}$and $\mathrm{Na}^{+}$as indicated at $37^{\circ} \mathrm{C}$ for $30 \mathrm{~min}$. (B) Divalent metal ion activation of rN-TcdB. UDP- $\left[{ }^{14} \mathrm{C}\right]$ glucose $(100 \mu \mathrm{M})$ was incubated in the presence of $\mathrm{rN}-\mathrm{TcdB}(100 \mathrm{nM})$ with the indicated divalent metal ions $(1 \mathrm{mM})$ at $37{ }^{\circ} \mathrm{C}$ for $30 \mathrm{~min}$. UDP- $\left[{ }^{14} \mathrm{C}\right]$ glucose and $\left[{ }^{14} \mathrm{C}\right]$ glucose were separated by thin layer chromatography on PEI cellulose and visualized by autoradiography. Signal intensities of formed $\left[{ }^{14} \mathrm{C}\right]$ glucose were quantified and are given as means $\pm \operatorname{SD}(n=3)$.

\subsection{Metal Ion Dependency of $r N-T c d B$}

TcsL and TcdB share a high identity on the level of amino acids (including the DxD motif) and exhibit comparable 3D structures [16,17]. Re-analysis of the divalent metal ion dependency of $\mathrm{rN}-\mathrm{TcdB}$ show that the glucosyltransferase (Figure 1) and UDP-glucose hydrolysis activity (Figure 4B) of rN-TcdB were activated by divalent metal ions with a rating: $\mathrm{Mn}^{2+}>\mathrm{Co}^{2+}>\mathrm{Mg}^{2+}>>\mathrm{Ca}^{2+}, \mathrm{Zn}^{2+}$, $\mathrm{Cu}^{2+}$. The divalent metal ion dependency of $\mathrm{rN}-\mathrm{TcdB}$ is highly comparable to that of rN-TcsL. The observations on the $\mathrm{rN}-\mathrm{TcdB}$ in vitro metal ion requirement of UDP-glucose hydrolysis activity is fully consistent with that formerly reported for full-length TcdB [19]. This consistency confirms that rN-TcdB and $\mathrm{rN}$-TcsL are appropriate models for the analysis of the metal ions dependency of the respective full-length toxins.

\subsection{Prebound Divalent Metal Ions Are Dispensible for Cytopathic Activity of TcsL and TcdB}

Cell entry of the LCGTs involves translocation of the N-terminal glucosyltransferase domain from the acid endosome to the cytoplasm by passing through a pore [24-26]. This mechanism most likely implies unfolding of the glucosyltransferse domain and the loss of bound factors including metal ions. Refolding of the $N$-terminal glucosyltransferase domain within the cytosol must be hypothesized to recruit intracellular metal ions for correct refolding and intracellular activation of the glucosylation reaction. This hypothesis implies that pre-bound divalent metal ions are not essential for the glucosylation reaction and the cytopathic effects of LCGTs. To corroborate this hypothesis, full-length TcsL and TcdB were depleted from divalent metal ions by incubation with EDTA for 1 $h$, followed by extensive dialysis against Tyrode's buffer. The cytopathic effect of TcdB and TcsL was analyzed in terms of the loss of the transepithelial resistance of a Madin-Darby canine kidney (MDCK-C7) monolayer [27]. Divalent metal ion-depleted toxin was either loaded with $\mathrm{Mn}^{2+}$ or left untreated and tested on MDCK-C7 monolayers maintained in Tyrode's buffer. Treatment with 
divalent metal ion-depleted and $\mathrm{Mn}^{2+}$-loaded TcdB and TcsL resulted in a time-dependent loss of the epithelial barrier function of the MDCK monolayer with comparable kinetics, as evidenced in terms of decreasing transepithelial resistance (TER) (Figure 5). This observation suggests that pre-bound metal ions are needed neither for cell entry nor for enzymatic activity. Since divalent metal ion-depleted TcdB and TcsL are inactive (Figures 2B and 4B), the glucosyltransferase domain of either TcdB and TcsL is most likely to recruit intracellular monovalent and divalent metal ions essential for substrate GTPase glucosylation and subsequent cytopathic activity. This view is strongly supported by a recent report showing that the solute carrier family 11 member 1 (SLC11A1), a divalent metal ion transporter, enhances TcdB-catalyzed substrate GTPase glucosylation and TcdB-induced loss of cell viability [28]. Thereby, increased sensitivity of $\mathrm{Mn}^{2+}$-pretreated cells to TcdB has been attributed to SLC11A1-dependent $\mathrm{Mn}^{2+}$ transport into the cells [28].

In sum, LCGT-catalyzed GTPase substrate glucosylation requires activation by intracellular monovalent and divalent metals. With regard to the free metal ion concentrations within mammalian target cells, LCGT must be hypothesized to recruit $\mathrm{K}^{+}$and $\mathrm{Mg}^{2+}$ for activation of the glucosyltransferase (despite $\mathrm{Mn}^{2+}$ being the most efficacious in vitro activator).

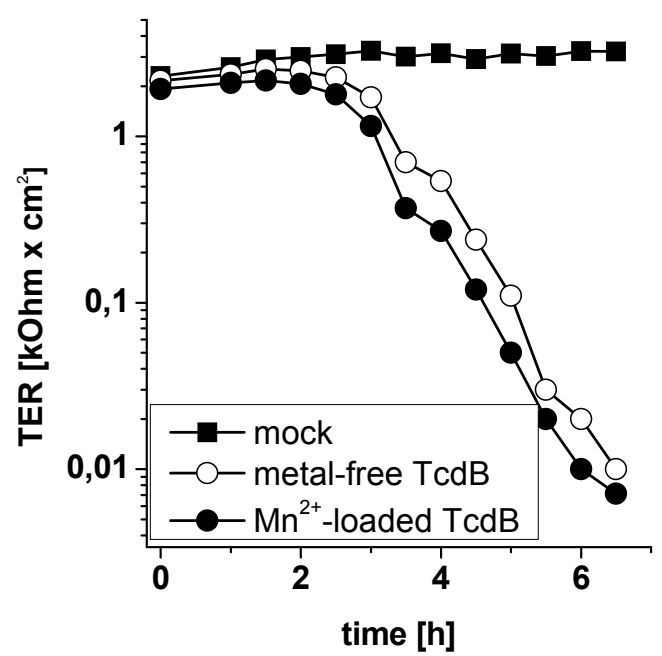

(A)

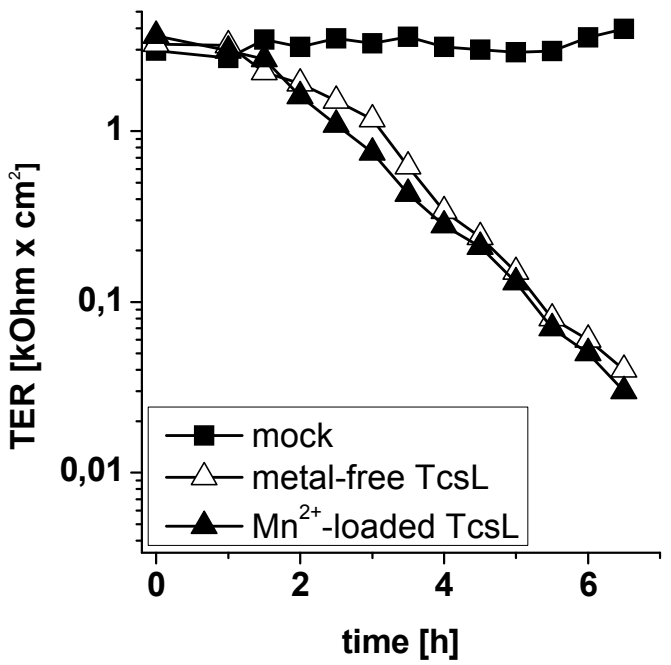

(B)

Figure 5. Prebound divalent metal ions are not required for cytopathic activity of TcsL and TcdB. Madin-Darby canine kidney (MDCK-C7) monolayers grown on Transwell filter inserts were treated with TcdB (10 ng/mL, A) and TcsL $(30 \mu \mathrm{g} / \mathrm{mL}, \mathrm{B})$. Transepithelial electrical resistance (TER) was monitored for the indicated times as a marker for toxin-uptake and activity. TER values are given as means $(n=3)$.

\section{Conclusions}

The glucosyltransferase and the UDP-glucose hydrolysis activity of TcsL and TcdB require both monovalent and divalent metal ions. The following rating is found for divalent metal ions: $\mathrm{Mn}^{2+}>$ $\mathrm{Co}^{2+}>\mathrm{Mg}^{2+}>>\mathrm{Ca}^{2+}, \mathrm{Cu}^{2+}, \mathrm{Zn}^{2+}$.

TcsL and TcdB share comparable monovalent and divalent metal ions requirement, consistent with comparable 3D structures of their glucosyltransferase domains.

TcsL and TcdB most likely recruit intracellular $\mathrm{K}^{+}$and $\mathrm{Mg}^{2+}$ for activation of the glucosyltransferase.

\section{Materials and Methods}

Materials-All reagents were of analytical grade and purchased from commercial sources. The glucosyltransferase domain (covering amino acids 1 to 546) of TcsL (rN-TcsL), TcdB (rN-TcdB), and 
Rac1 were recombinantly expressed in E. coli and purified as GST fusion proteins as described [20]. TcsL and TcdB were prepared from C. sordellii strain 6018 and C. difficile strain VPI10463, respectively, as previously described [15,29].

Transepithelial resistance of MDCK-C7 monolayers-Madin-Darby canine kidney (MDCK-C7) cells were cultured under standard conditions $\left(37^{\circ} \mathrm{C}, 5 \% \mathrm{CO}_{2}\right)$ as described [27]. Briefly, MDCK-C7 cells were cultured in minimum essential medium (MEM) enriched with Earle's salts, non-essential amino acids, glutamic acid, and 10\% fetal calf serum (Biochrom, Berlin, Germany) and split twice weekly using standard culture techniques. MDCK-C7 cells were seeded onto 12-well filter transwell inserts (pore size $0.4 \mu \mathrm{M}$, Becton Dickinson, Heidelberg, Germany). The transepithelial electrical resistance (TER) was determined by a Voltohmmeter equipped with Endom 24 chamber (EVOM, World Precision Instruments, Berlin, Germany). MDCK-C7 monolayers were cultivated up to an initial resistance of $>2 \mathrm{k} \Omega \cdot \mathrm{cm}^{2}$. The medium was exchanged for HEPES-buffered Tyrode's solution $(25 \mathrm{mM}$ of HEPES, pH 7.4, $120 \mathrm{mM} \cdot \mathrm{NaCl}, 5 \mathrm{mM} \cdot \mathrm{KCl}, 2 \mathrm{mM} \cdot \mathrm{CaCl}_{2}$, and $6 \mathrm{~g} / \mathrm{L}$ of glucose). The toxins were applied on the basolateral site of the monolayer and toxin-induced loss of TER was analyzed in a time-dependent manner.

Glucosyltransferase activity-Recombinant Rac1 $(50 \mu \mathrm{g} / \mathrm{mL})$ was incubated with either rN-TcsL or rN-TcdB, $20 \mu \mathrm{M}$ of UDP-[ $\left[{ }^{14} \mathrm{C}\right]$ glucose (Biotrend, Cologne, Germany), and the indicated divalent metal ions (1 mM) in glucosylation buffer (50 mM of HEPES pH 7.4, $0.1 \mathrm{mM} \cdot \mathrm{MgCl}_{2}, 150 \mathrm{mM} \cdot \mathrm{KCl}$, $100 \mu \mathrm{g} / \mathrm{mL}$ of BSA) in a total volume of $20 \mu \mathrm{L}$ at $37^{\circ} \mathrm{C}$ for $10 \mathrm{~min}$. Proteins were analyzed by $12.5 \%$ SDS-PAGE, and $\left[{ }^{14} \mathrm{C}\right]$ glucosylated Rac1 was visualized by PhosphorImaging (Cyclone, PerkinElmer Life and Analytical Sciences, Shelton, CT, USA).

Glycohydrolase activity-The toxins were incubated with $100 \mu \mathrm{M}$ of UDP- $\left[{ }^{14} \mathrm{C}\right]$ glucose in glycohydrolase buffer (50 mM of HEPES, pH 7.4, supplemented with either $150 \mathrm{mM} \cdot \mathrm{KCl}$ or $\mathrm{NaCl}$, and $100 \mu \mathrm{g} / \mathrm{mL}$ of BSA) in the presence of the indicated concentrations of divalent metal ions. Samples of a total volume of $10 \mu \mathrm{L}$ were incubated at $37^{\circ} \mathrm{C}$ for $30 \mathrm{~min} .2 \mu \mathrm{L}$ samples were taken as indicated and run on PEI-cellulose plates (Merck, Darmstadt, Germany) using $0.2 \mathrm{mM} \cdot \mathrm{LiCl}$ as mobile phase. The plates were dried and analyzed using PhosphorImager. Quantitative data are given as mol formed $\left[{ }^{14} \mathrm{C}\right]$ glucose per mol toxin and per time indicated as means $\pm \operatorname{SD}(n=3)$.

Data analysis-Initial rate data for the glycohydrolase reaction were determined with regard to metal ion binding by varying the metal ion concentration. The $\mathrm{EC}_{50}$ values were obtained by a non-linear curve fitting using the sigmoid $\mathrm{E}_{\max }$ model (the Hill equation).

Acknowledgments: This work was supported by Niedersachsen Vorab grant number: VWZN2889.

Author Contributions: H.G. and I.J. conceived and designed the experiments; H.G. and I.S. performed the experiments; H.G. and I.S. analyzed the data; H.G. and I.J. wrote the paper.

Conflicts of Interest: The authors declare no conflict of interest.

\section{Abbreviations}

The following abbreviations are used in this manuscript:

LCGT Large clostridial glycosylating toxin

PEI Polyethylenimine-modified

TcdA C. difficile toxin A

TcdB C. difficile toxin B

Tcn $\alpha$ C. novyi alpha-toxin from, and the glycosylating toxin

TcpE Glycosylating toxin from C. perfringens type E strain

TcsL C. sordellii lethal toxin

TcsH C. sordellii hemorrhagic toxin 


\section{References}

1. Popoff, M.R.; Geny, B. Rho/Ras-GTPase-dependent and -independent activity of clostridial glucosylating toxins. J. Med. Microbiol. 2011, 60, 1057-1069. [CrossRef] [PubMed]

2. Jank, T.; Belyi, Y.; Aktories, K. Bacterial glycosyltransferase toxins. Cell. Microbiol. 2015, 17, $1752-1765$. [CrossRef] [PubMed]

3. Genth, H.; Pauillac, S.; Schelle, I.; Bouvet, P.; Bouchier, C.; Varela-Chavez, C.; Just, I.; Popoff, M.R. Haemorrhagic toxin and lethal toxin from Clostridium sordellii strain vpi9048: Molecular characterization and comparative analysis of substrate specificity of the large clostridial glucosylating toxins. Cell. Microbiol. 2014, 16, 1706-1721. [CrossRef] [PubMed]

4. Huelsenbeck, S.C.; Klose, I.; Reichenbach, M.; Huelsenbeck, J.; Genth, H. Distinct kinetics of (H/K/N)Ras glucosylation and Rac1 glucosylation catalysed by Clostridium sordellii lethal toxin. FEBS Lett. 2009, 583, 3133-3139. [CrossRef] [PubMed]

5. Genth, H.; Just, I. Functional implications of lethal toxin-catalysed glucosylation of (H/K/N)Ras and Rac1 in Clostridium sordellii-associated disease. Eur. J. Cell Biol. 2011, 90, 959-965. [CrossRef] [PubMed]

6. Vetter, I.R.; Hofmann, F.; Wohlgemuth, S.; Herrmann, C.; Just, I. Structural consequences of mono-glucosylation of Ha-Ras by Clostridium sordellii lethal toxin. J. Mol. Biol. 2000, 301, 1091-1095. [CrossRef] [PubMed]

7. Geyer, M.; Wilde, C.; Selzer, J.; Aktories, K.; Kalbitzer, H.R. Glucosylation of Ras by Clostridium sordellii lethal toxin: Consequences for effector loop conformations observed by NMR spectroscopy. Biochemistry 2003, 42, 11951-11959. [CrossRef] [PubMed]

8. May, M.; Kolbe, T.; Wang, T.; Schmidt, G.; Genth, H. Increased cell-matrix adhesion upon constitutive activation of rho proteins by cytotoxic necrotizing factors from E. coli and Y. pseudotuberculosis. J. Signal Transduct. 2012, 2012, 570183. [CrossRef] [PubMed]

9. Geny, B.; Grassart, A.; Manich, M.; Chicanne, G.; Payrastre, B.; Sauvonnet, N.; Popoff, M.R. Rac1 inactivation by lethal toxin from Clostridium sordellii modifies focal adhesions upstream of actin depolymerization. Cell. Microbiol. 2010, 12, 217-232. [CrossRef] [PubMed]

10. Boehm, C.; Gibert, M.; Geny, B.; Popoff, M.R.; Rodriguez, P. Modification of epithelial cell barrier permeability and intercellular junctions by Clostridium sordellii lethal toxins. Cell. Microbiol. 2006, 8, 1070-1085. [CrossRef] [PubMed]

11. Petit, P.; Bréard, J.; Montalescot, V.; El Hadj, N.B.; Levade, T.; Popoff, M.; Geny, B. Lethal toxin from Clostridium sordellii induces apoptotic cell death by disruption of mitochondrial homeostasis in HL-60 cells. Cell. Microbiol. 2003, 5, 761-771. [CrossRef] [PubMed]

12. Dreger, S.C.; Schulz, F.; Huelsenbeck, J.; Gerhard, R.; Hofmann, F.; Just, I.; Genth, H. Killing of rat basophilic leukemia cells by lethal toxin from Clostridium sordellii: Critical role of phosphatidylinositide 3'-OH kinase/Akt signaling. Biochemistry 2009, 48, 1785-1792. [CrossRef] [PubMed]

13. Huelsenbeck, J.; May, M.; Schulz, F.; Schelle, I.; Ronkina, N.; Hohenegger, M.; Fritz, G.; Just, I.; Gerhard, R.; Genth, H. Cytoprotective effect of the small GTPase RhoB expressed upon treatment of fibroblasts with the Ras-glucosylating Clostridium sordellii Lethal Toxin. FEBS Lett. 2012, 586, 3665-3673. [CrossRef] [PubMed]

14. Huelsenbeck, J.; Dreger, S.C.; Gerhard, R.; Fritz, G.; Just, I.; Genth, H. Upregulation of the immediate early gene product RhoB by exoenzyme $\mathrm{C} 3$ from Clostridium limosum and toxin B from Clostridium difficile. Biochemistry 2007, 46, 4923-4931. [CrossRef] [PubMed]

15. May, M.; Wang, T.; Muller, M.; Genth, H. Difference in F-actin depolymerization induced by toxin B from the Clostridium difficile strain VPI 10463 and toxin B from the variant Clostridium difficile serotype F strain 1470. Toxins (Basel). 2013, 5, 106-119. [CrossRef] [PubMed]

16. Ziegler, M.O.; Jank, T.; Aktories, K.; Schulz, G.E. Conformational changes and reaction of clostridial glycosylating toxins. J. Mol. Biol. 2008, 377, 1346-1356. [CrossRef] [PubMed]

17. Reinert, D.J.; Jank, T.; Aktories, K.; Schulz, G.E. Structural basis for the function of Clostridium difficile toxin B. J. Mol. Biol. 2005, 351, 973-981. [CrossRef] [PubMed]

18. D'Urzo, N.; Malito, E.; Biancucci, M.; Bottomley, M.J.; Maione, D.; Scarselli, M.; Martinelli, M. The structure of Clostridium difficile toxin A glucosyltransferase domain bound to $\mathrm{Mn}^{2+}$ and UDP provides insights into glucosyltransferase activity and product release. FEBS J. 2012, 279, 3085-3097. [CrossRef] [PubMed] 
19. Ciesla, W.P., Jr; Bobak, D.A. Clostridium difficile toxins A and B are cation-dependent UDP-glucose hydrolases with differing catalytic activities. J. Biol. Chem. 1998, 273, 16021-16026. [CrossRef] [PubMed]

20. Busch, C.; Hofmann, F.; Selzer, J.; Munro, J.; Jeckel, D.; Aktories, K. A common motif of eukaryotic glycosyltransferases is essential for the enzyme activity of large clostridial cytotoxins. J. Biol. Chem. 1998, 273, 19566-19572. [CrossRef] [PubMed]

21. Powell, J.T.; Brew, K. Affinity labeling of bovine colostrum galactosyltransferase with a uridine 5'-diphosphate derivative. Biochemistry 1976, 15, 3499-3505. [CrossRef] [PubMed]

22. Wiggins, C.A.R.; Munro, S. Activity of the yeast MNN1 a-1,3-mannosyltransferase requires a motif conserved in many other families of glycosyltransferases. Proc. Natl. Acad. Sci. USA 1998, 95, 7945-7950. [CrossRef] [PubMed]

23. Di, C.E. A structural perspective on enzymes activated by monovalent cations. J. Biol. Chem. 2006, 281, 1305-1308.

24. Reineke, J.; Tenzer, S.; Rupnik, M.; Koschinski, A.; Hasselmayer, O.; Schrattenholz, A.; Schild, H.; von Eichel-Streiber, C. Autocatalytic cleavage of Clostridium difficile toxin B. Nature 2007, 446, 415-419. [CrossRef] [PubMed]

25. Egerer, M.; Giesemann, T.; Jank, T.; Satchell, K.J.; Aktories, K. Auto-catalytic cleavage of Clostridium difficile toxins A and B depends on cysteine protease activity. J. Biol. Chem. 2007, 282, 25314-25321. [CrossRef] [PubMed]

26. Papatheodorou, P.; Zamboglou, C.; Genisyuerek, S.; Guttenberg, G.; Aktories, K. Clostridial glucosylating toxins enter cells via clathrin-mediated endocytosis. PLoS ONE 2010, 5, e10673. [CrossRef] [PubMed]

27. Zak, J.; Schneider, S.W.; Eue, I.; Ludwig, T.; Oberleithner, H. High-resistance MDCK-C7 monolayers used for measuring invasive potency of tumour cells. Pflug. Arch. 2000, 440, 179-183. [CrossRef]

28. Feng, Y.; Cohen, S.N. Upregulation of the host SLC11A1 gene by Clostridium difficile toxin B facilitates glucosylation of Rho GTPases and enhances toxin lethality. Infect. Immun. 2013, 81, 2724-2732. [CrossRef] [PubMed]

29. Genth, H.; Selzer, J.; Busch, C.; Dumbach, J.; Hofmann, F.; Aktories, K.; Just, I. New method to generate enzymatically deficient Clostridium difficile toxin B as an antigen for immunization. Infect. Immun. 2000, 68, 1094-1101. [CrossRef] [PubMed] 